\title{
Epithelial-mesenchymal transition regulated by p38/MAPK signaling pathways participates in vasculogenic mimicry formation in SHG44 cells transfected with TGF- $\beta$ cDNA loaded lentivirus in vitro and in vivo
}

\author{
GENGQIANG LING $^{1,2^{*}}$, QIAO JI ${ }^{2 *}$, WEI YE ${ }^{1}$, DONGYING MA ${ }^{1}$ and YUENA WANG ${ }^{1}$ \\ ${ }^{1}$ Department of Neurosurgery, Second Affiliated Hospital of Harbin Medical University, Harbin, Heilongjiang; \\ ${ }^{2}$ Key Laboratory of Myocardial Ischemia, Harbin Medical University, Ministry of Education, Heilongjiang, P.R. China
}

Received July 20, 2016; Accepted October 4, 2016

DOI: 10.3892/ijo.2016.3724

\begin{abstract}
TGF- $\beta$-induced epithelial-mesenchymal transition (EMT) plays an important role in tumor progression. We assessed whether the TGF- $\beta$-induced EMT contributed to vasculogenic mimicry (VM) formation in glioma, we established an SHG44 cell line stably transfected with TGF- $\beta$ cDNA loaded lentivirus. SB203580 was employed to inhibit the TGF- $\beta$-induced EMT. The results showed that the VM forming ability of cells could be improved by TGF- $\beta$ overexpression. The migration and invasion capabilities of cells were also enhanced due to EMT. SB203580 was able to weaken cell migration, invasion and VM forming abilities via blocking p38/MAPK signaling pathways, but it had tiny influence on MMP/LAMC2 chain. Consequently, we concluded that EMT inhibition via p38/MAPK signaling pathways would partly impair TGF- $\beta$-induced VM formation in glioma.
\end{abstract}

\section{Introduction}

Antiangiogenic therapy is currently the dominating experimental therapeutic strategy for glioma (1). Traditional antiangiogenic therapy is aimed at endothelial angiogenesis via the sprouting of new vessels from the existing ones, thus, limited the volume of tumor in certain stages (2). However, it failed to eliminate tumor probably because of the existence of other supplemental blood supply systems, e.g., vasculogenic mimicry (VM) (3). VM is a formation of de novo vasculogeniclike matrix-embedded networks, i.e. vascular-like structures,

Correspondence to: Dr Gengqiang Ling, Department of Neurosurgery, Second Affiliated Hospital of Harbin Medical University, 194 Xuefu Road, Harbin, Heilongjiang 150086, P.R. China E-mail: lgq1013@163.com

*Contributed equally

Key words: glioma, epithelial-mesenchymal transition, lentivirus, vasculogenic mimicry, TGF- $\beta$, p38/MAPK containing plasma and red blood cells and ultimately contributing to blood circulation (4). VM helped to keep tumor cells nourished in hypoxic and ischemic environment (5), thus, weakened the effect of antiangiogenic therapy or even elicited greater malignancy $(6,7)$. Consequently, researchers suggested that both antiangiogenic and anti-VM treatments should be applied during antitumor therapy $(8,9)$.

To date, the capability of VM formation has been considered to be a marker of patients' prognosis according to some research (10-12). Therefore, it is important to clarify the mechanism of VM formation and block its signaling pathways accordingly. Chen and Chen (9) suggested that anti-VM therapy should focus on inhibiting tumor cell plasticity as well as blocking the biochemical and molecular pathways remodeling the ECM and tumor microenvironment in VM. Tumor cell plasticity means their capacity to adapt to the selective pressures they encounter during tumor development (13). In some cases, highly malignant tumor cells could turn back into an embryonic 'stem' state and acquire multi-potential capacity. With the embryonic 'stem' state, tumor cells were able to either mimic the biological behavior of endothelial cells (VM) or differentiate into endothelial cells for supporting the circulation (14). However, the mechanism and process of 'stem' transition has not been understood clearly.

In recent years, epithelial-mesenchymal transition (EMT) has been reported to contribute to VM formation $(15,16)$. EMT is a process that epithelial-type cells undergo a developmental switch associated with the downregulation of epithelial cell surface markers and cytoskeleton components (e.g., E-cadherin and cytokeratins) and the upregulation of mesenchymal markers and extracellular matrix components (e.g., N-cadherin and fibronectin) (17). Once the EMT process was inhibited, the invasive behavior of tumor cells would be suppressed (18). It is increasingly acknowledged that EMT is a very important process of conferring stem cell properties to normal cancer cells (19). Loss of epithelial characteristics and acquisition of a mesenchymal phenotype not only enhanced the migratory and invasive potential of tumor cells, but also enabled their self-renewal and tumor-initiating capabilities (20). In the EMT process, transforming growth factor- $\beta$ 
(TGF- $\beta$ ) played a key role. It was suggested that TGF- $\beta$ induced EMT and cell transformation is one of the earliest events in tumor progression (21). TGF- $\beta$ inhibition could impair the capability of angiogenesis by suppressing the secretion of vascular endothelial growth factor (VEGF) $(22,23)$. In addition, our previous study showed that TGF- $\beta$ inhibition led to an impaired in vitro VM formation in glioma cell line U251MG by suppressing the expression of MT1-MMP (24). MT1-MMP promoted the pro-MMP transition into its active form. Then, MMP2 activation leads to LAMC2 chain cleavage into pro-migratory $\mathrm{C} 2$ and $\mathrm{C} 2 \mathrm{x}$ fragments. These fragments are deposited in the ECM and participate in matrix plasticity, cell migration, invasion and VM formation (25). Based on the above, we wondered whether the TGF- $\beta$-induced EMT participated in the process of glioma VM formation. If so, we would investigate its inner mechanism. For this purpose, we established in vitro and in vivo models of a less invasive glioma cell line SHG44 pre-transfected with lentivirus loaded with scramble gene or TGF- $\beta$ cDNA. SB203580, a specific inhibitor of p38/MAP kinase signaling pathway was also used to block the process of EMT without impact on TGF- $\beta$ in the present study.

\section{Materials and methods}

Construction of lentivirus vector loaded with TGF- $\beta$ cDNA. The GV358 vector (data not shown) was provided by Shanghai Genechem, Co., Ltd., (Shanghai, China) and re-confirmed by sequencing. TGF- $\beta$ mRNA was extracted and cDNA was synthesized using quantitative PCR with primers containing enzymatic digestion sites for AgeI/AgeI, according to the manufacturer's instructions. The primers corresponded to NCBI Reference Sequence (NM_000660) forward, 5'-GAG GAT CCC CGG GTA CCG GTC GCC ACC ATG CCG CCC TCC GGG CT-3' and reverse, 5'-TCC TTG TAG TCC ATA CCG CTG CAC TTG CAG GAG CGC ACG-3'. The TGF- $\beta$ cDNA (data not shown) was packed into the GV358 vector to form the pLV-TGF $\beta$ vector. Following the sequencing, the recombinant segment of the correct clone was incised by AgeI/AgeI. The pLV-TGF $\beta$ clones were sequenced and the correct clones were amplified and identified by restriction enzyme digestion. The 293T cells were transfected with the pLV-TGF $\beta$ for virus packing. The supernatants of transfected 293T cells were collected and tested for virus titer by ELISA. Empty GV358 vector served as a negative control.

Cell culture and grouping. The human SHG44 glioma cell line (Laboratory Animal Center of Sun Yat-sen University, Guangzhou, China) was maintained in high glucose Dulbecco's modified Eagle's medium (DMEM; Invitrogen, 11995065) supplemented with $10 \%$ fetal bovine serum (FBS; HyClone Laboratories, $\mathrm{SV} 30087.02)$ in $5 \% \mathrm{CO}_{2}$ at $37^{\circ} \mathrm{C}$. Cultures were passaged every 2 to 3 days until $80 \%$ confluent. The specific inhibitor of p38/MAPK signaling pathway, SB203580 was purchased from Selleck Chemicals, Co., Ltd. (Houston, TX, USA). Three groups of cells were established, i.e. NC group (transfected with empty GV358), pLV-TGF $\beta+$ SB203580 group (transfected with GV358 loaded with TGF- $\beta$ cDNA, added with $10 \mu \mathrm{M} /$ day SB203580), and pLV-TGF $\beta$ group (transfected with GV358 loaded with TGF- $\beta$ cDNA, without SB203580).
Establishment of a stable transfected cell line. SHG44 cells were seeded into a 24-well plate at a density of $10^{5}$ cells/well. Twelve hours later, the cells were transiently transfected with pLV-TGF $\beta$ with a titer of $10^{6}$ each well. Two days after transfection, green fluorescence could be observed using a fluorescence inverted microscope (DMI4000; Leica Microsystems, Inc., Wetzlar, Germany). Later, puromycin (Genomeditech, Co., Ltd., Shanghai, China; GM-040401-1) at a concentration of $5 \mu \mathrm{g} / \mathrm{ml}$ was used to screen cells that were successfully transfected. After screening for 5 days, enriched transfected cell populations were picked out and maintained with puromycin at a concentration of $2 \mu \mathrm{g} / \mathrm{ml}$ for further experiments. Clones were expanded for another 2 weeks.

In vitro tube formation, invasion and migration assays. Tube formation assay was carried out as previously described (24). Briefly, wells of 24-well plate were coated with Matrigel basement membrane matrix (BD Biosciences, San Jose, CA, USA) at $0.2 \mathrm{ml} / \mathrm{well}$. It was allowed to polymerase at $37^{\circ} \mathrm{C}$ for $1 \mathrm{~h}$. Cells were resuspended and seeded into a well at a density of $5 \times 10^{5}$ cells $/ \mathrm{ml}$, then incubated without serum in $5 \% \mathrm{CO}_{2}$ at $37^{\circ} \mathrm{C}$ for $24 \mathrm{~h}$. Cultures were photographed using fluorescence inverted microscope (DMI4000; Leica Microsystems) $24 \mathrm{~h}$ later. The total length of tubes per field was quantified by counting in 5 randomly chosen $100 \mathrm{X}$ scopes using Leica application suite v3.60 (Leica Microsystems). The cell invasion assay was evaluated using Transwell filters with $6.5 \mathrm{~mm}$ diameters and $8 \mu \mathrm{m}$ pore sizes (Corning, 3422). The filters were coated with $50 \mu 1$ Matrigel diluted with serum-free medium (1:3) for $30 \mathrm{~min}$ at $37^{\circ} \mathrm{C}$ according to the manufacturer's instructions. The cells $\left(1 \times 10^{5}\right)$ were seeded with $100 \mu \mathrm{l}$ serum-free medium into the upper chamber while $500 \mu 1$ complete medium (containing 10\% FBS) was placed in the lower chamber. The plates were placed at $37^{\circ} \mathrm{C}$ in $5 \% \mathrm{CO}_{2}$ for $24 \mathrm{~h}$. The upper chambers were fixed with $4 \% \mathrm{PFA}$ and stained with $0.1 \%$ crystal violet for $30 \mathrm{~min}$. The cells on the upper surface of the chamber were removed, and the stained cells on the lower surface of the chamber were counted. Images of at least ten random fields per chamber were captured (magnification, $\mathrm{x} 20$ ). The cells for wound healing assay were allowed to grow to $80 \%$ and scratched using a $1 \mathrm{ml}$ pipette tip in the central area. For removing floating cells and slowing down the growth, the medium was changed to serum-free. The cells were incubated for $48 \mathrm{~h}$ to close the wound. Images were taken at the same position of the wound at 24 and $48 \mathrm{~h}$.

Cell proliferation assay. The cell proliferation assay was evaluated using a Cell Counting kit-8 (CCK-8) (Shanghai Haoran Biotechnology, Co., Ltd., Shanghai, China). In short, cells were planted into wells of a 96-well plate with $10 \%$ FBS in the culture medium at a density of $1 \times 10^{3}$ cells/well, and then daily added with $10 \mu$ l CCK- 8 for 7 days. Cultures were incubated in $5 \% \mathrm{CO}_{2}$ at $37^{\circ} \mathrm{C}$ for $4 \mathrm{~h}$ following daily CCK-8 administration. Supernatants were obtained by centrifuging at $1,000 \mathrm{x} \mathrm{g}$ for $20 \mathrm{~min}$. The absorbance of the supernatant from each well was detected at $450 \mathrm{~nm}$ using a microplate reader (model 550; Bio-Rad Laboratories, Inc., Hercules, CA, USA).

Establishment of tumor xenograft model and grouping. Four to six weeks old BALB/c-nu nude mice were bought from Vital 
Table I. Primers sequences for RT-PCR.

\begin{tabular}{|c|c|c|}
\hline Gene & Primer sequence & Product (bp) \\
\hline Smad2 & $\begin{array}{l}\text { Sense: 5'-TTCCAGACTTTGTGCTGTCCAGTAA-3' } \\
\text { Antisense: 5'-AGGGCAGAGGCTCCACTGAGTA-3' }\end{array}$ & 120 \\
\hline p38 & $\begin{array}{l}\text { Sense: 5'-TCGAGACCGTTTCAGTCCAT-3' } \\
\text { Antisense: 5'-CCACGGACCAAATATCCACT-3' }\end{array}$ & 463 \\
\hline TGF- $\beta$ & $\begin{array}{l}\text { Sense: 5'-GACTACTACGCCAAGGAG-3' } \\
\text { Antisense: 5'-TGAGGTATCGCCAGGAAT-3' }\end{array}$ & 244 \\
\hline E-cadherin & $\begin{array}{l}\text { Sense: 5'-AGGCCTCTACGGTTTCATAA-3' } \\
\text { Antisense: 5'-AATGTTGGAGGAATTACGTCA-3' }\end{array}$ & 540 \\
\hline $\mathrm{N}$-cadherin & $\begin{array}{l}\text { Sense: 5'-TGCGGTACAGTGTAACTGGGCCAGG-3' } \\
\text { Antisense: 5'-TGCGGTACAGTGTAACTGGGCCAGG-3' }\end{array}$ & 438 \\
\hline MT1-MMP & $\begin{array}{l}\text { Sense: 5'-AGCAACTTTATGGGGGTGAGT-3' } \\
\text { Antisense: 5'-CCAGACTTTGATGTTCTTGGGG-3' }\end{array}$ & 530 \\
\hline LAMC2 & $\begin{array}{l}\text { Sense: 5'-AGCAGAAAGCCACGTTGAGT-3' } \\
\text { Antisense: 5'-CAGGGACTTGGTTTTCTCCA-3' }\end{array}$ & 187 \\
\hline$\beta$-actin & $\begin{array}{l}\text { Sense: 5'-CTCCATCCTGGCCTCGCTGT-3' } \\
\text { Antisense: 5'-GCTGTCACCTTCACCGTTCC-3' }\end{array}$ & 268 \\
\hline
\end{tabular}

River Experimental Animal Technology, Co., Ltd. (Beijing, China). All experiments were performed in accordance with the official recommendations of the Chinese Community Guidelines. SHG44 transfected with empty vector or TGF- $\beta$ cDNA vector ( $\mathrm{pLV}$-TGF $\beta$ ) were prepared. Cells were resuspended at a density of $5 \times 10^{7} / \mathrm{ml}$ and subcutaneously injected into the right flank of each nude mouse. Three groups of mice $(n=6)$ were established, i.e. NC group (cells transfected with empty GV358), pLV-TGF $\beta+$ SB203580 group (cells transfected with pLV-TGF $\beta$, with $250 \mu \mathrm{M}$ SB203580 dissolving in drinking water), and pLV-TGF $\beta$ group (cells transfected with pLV-TGF $\beta$, without SB203580 feeding). Twelve days after injection, the subcutaneous tumors were palpable. One month later, animals were euthanized and the xenografts were obtained for further experiments.

Enzyme-linked immunosorbent assay (ELISA). The concentration of TGF- $\beta$ in the supernatant of cell medium was detected using a TGF- $\beta$ ELISA kit (Invitrogen, LHG0121). The supernatant was collected and assayed following the manufacturer's instructions. Absorbance detection was performed at $450 \mathrm{~nm}$ using a microplate reader (Bio-Rad Laboratories).

Semi-quantitative reverse transcriptase-polymerase chain reaction $(R T-P C R)$. Total RNA was extracted from cells or xenografts using TRIZol (Invitrogen, 15596026). Then, we synthesized cDNA using a reverse transcription kit (Invitrogen, 28025021) following the manufacturer's instructions. Primer sequences used for PCR were synthesized by Invitrogen as shown in Table I. Platinum PCR SuperMix High Fidelity (Invitrogen, 12532016) was used for PCR amplifications. The conditions were as follows: $5 \mathrm{~min}$ at $94^{\circ} \mathrm{C}$ for denaturation, followed by $30 \mathrm{sec}$ at $94^{\circ} \mathrm{C}, 30 \mathrm{sec}$ at $55^{\circ} \mathrm{C}$ and $1 \mathrm{~min}$ at $72^{\circ} \mathrm{C}$ for 35 cycles and $5 \mathrm{~min}$ at $72^{\circ} \mathrm{C}$ for final elongation. The PCR products were electrophoretically analysed in $1.5 \%$ agarose (Invitrogen, 16500500) and visualized by ethidium bromide (Sigma-Aldrich, 46065) staining. Then the agarose gel was photographed using a PM-CBAD image system (Olympus, Tokyo, Japan). Bands were analyzed using ImageJ v1.48 software (National Institutes of Health, Bethesda, ME, USA). $\beta$-actin served as internal control.

Immunohistochemistry. Standard immunohistochemical staining was performed on paraffin-embedded tumor sections, at $5 \mu \mathrm{m}$. Slides were deparaffinized using xylene and absolute ethanol, rinsed in distilled water, exposed to $3 \% \mathrm{H}_{2} \mathrm{O}_{2}$ for $10 \mathrm{~min}$, and then immersed in sodium citrate antigen-unmasking solution. The antigen-unmasking solution together with the slides were heated in an oven at $90^{\circ} \mathrm{C}$ for $15 \mathrm{~min}$, and then cooled to room temperature. The sections were rinsed with PBS and blocked subsequently with $10 \%$ goat serum. Sections were stained with primary antibodies for $1 \mathrm{~h}$ at $36.5^{\circ} \mathrm{C}$, and then incubated for $40 \mathrm{~min}$ at $36.5^{\circ} \mathrm{C}$ with biotinylated immunoglobulins in PBS. The following primary antibodies were used to detect the positive cells: E-cadherin (Abcam, ab40772), N-cadherin (Abcam, ab18203) and CD34 (Abcam, ab81289). Sections were exposed to diaminobenzidine tetrahydrochloride chromogen for $5 \mathrm{~min}$, and rinsed in distilled water (all the reagents were purchased from Wuhan Boster Biological Technology, Ltd., Wuhan, China). Finally, slides were counterstained with Mayer's hematoxylin (Wuhan Boster Biological Technology) for $1 \mathrm{~min}$ and coverslipped with a permanent mounting medium. Immuno-positive area in each slide was calculated using Image-Pro Plus (Media Cybernetics, Inc., Rockville, MD USA). The assessment of immunohistochemistry results was completed by two independent investigators blinded to the animal data. 
CD34 and periodic acid-Schiff (PAS) dual staining and in vivo tube formation assay. CD34-PAS dual staining was carried out following Yue and Chen (26). Briefly, standard immunohistochemical staining was performed on paraffin-embedded tumor sections, at $5 \mu \mathrm{m}$. The details of CD34 immunohistochemistry were described previously. Sections were exposed to periodic acid (Wuhan Boster Biological Technology) for 15 min, then with Schiff reagent (Wuhan Boster Biological Technology) for $60 \mathrm{~min}$. Finally, they were counterstained with Mayer's hematoxylin for $10 \mathrm{~min}$ and coverslipped. These slides were observed under a light microscope. The presence of VM [CD34-negative and PAS-positive tubes, evaluated according to the criteria of Folberg et al (27)] and endothelial vessels (CD34-positive and PAS-positive tubes) were assessed. The number of VM was quantified in 5 randomly chosen 200x scopes using LEICA application suite v3.60 (Leica Microsystems).

Western blot analysis. Cells or kibbling tissue of xenografts were lysed with cold RIPA buffer $(50 \mathrm{mM}$ of Tris- $\mathrm{HCl}$, $\mathrm{pH} 8.0,150 \mathrm{mM}$ of $\mathrm{NaCl}, 0.5 \%$ sodium deoxycholate, $1.0 \%$ NP-40, $0.1 \%$ SDS, $100 \mu \mathrm{l} / \mathrm{ml}$ of proteinase inhibitor aprotinin) for $30 \mathrm{~min}$ (all the reagents above were from Wuhan Boster Biological Technology). Then, the lysates were centrifuged at $12,000 \mathrm{x} \mathrm{g}$ for $15 \mathrm{~min}$ at $4^{\circ} \mathrm{C}$. Protein concentration was confirmed using the Bradford assay. Average amounts of protein were mixed with loading buffer $(0.125 \mathrm{M}$ Tris- $\mathrm{HCl}$, pH 6.8, 10\% glycerol, 2\% $\beta$-mercaptoethanol, $2 \%$ SDS and $0.1 \%$ bromophenol blue) and boiled for $10 \mathrm{~min}$ (all the reagents were from Wuhan Boster Biological Technology). After electrophoresis, proteins were transferred to PVDF membrane using a standard protocol. The membrane was blocked in $2 \%$ BSA for $2 \mathrm{~h}$, rinsed and then incubated with primary antibody for $1 \mathrm{~h}$ at $37^{\circ} \mathrm{C}$. The following primary antibodies were used to detect bands on the protein blots: MT1-MMP (Abcam, ab53712), LAMC2 (Abcam, ab96327), P38 (Abcam, ab7952), phospho-P38 (Abcam, ab4822), Smad2 (Abcam, ab63576), phospho-Smad2 (Abcam, ab53100), E-cadherin (Abcam, ab40772), N-cadherin (Abcam, ab18203), $\beta$-actin (Abcam, ab129348). Thereafter, membranes were washed with TBST (TBS containing $0.01 \%$ Tween-20) and incubated for $1 \mathrm{~h}$ at $37^{\circ} \mathrm{C}$ with HRP-conjugated secondary antibodies. Bands were visualized by an enhanced chemiluminescence (ECL) kit (Invitrogen, WP20005), exposed to radiography film and analyzed using ImageJ v1.43 software. $\beta$-actin served as internal control.

Gelatin zymography analysis. Gelatin zymography was employed to detect MMP-2 and MMP-9 activities. The supernatants of serum-free cultures were collected and centrifuged at 2,000 x g for $10 \mathrm{~min}$ and then subjected to SDS-PAGE with $0.1 \%$ gelatin and $30 \%$ polyacrylamide gel. Electrophoresis was run at constant $80 \mathrm{~V}$ in spacer gel and at constant $120 \mathrm{~V}$ in separation gel at $4^{\circ} \mathrm{C}$. Then the gel was washed with eluent (2.5\% Triton X-100, $50 \mathrm{mmol} / 1 \mathrm{Tris}-\mathrm{HCl}, 5 \mathrm{mmol} / 1 \mathrm{CaCl}_{2}$, $1 \mathrm{mmol} / 1 \mathrm{ZnCl}_{2}, \mathrm{pH}$ 7.6) for $1 \mathrm{~h}$, later with rinse water (50 mmol/1 Tris- $\mathrm{HCl}, 5 \mathrm{mmol} / 1 \mathrm{CaCl}_{2}, 1 \mathrm{mmol} / 1 \mathrm{ZnCl}_{2}$, $\mathrm{pH}$ 7.6) for $30 \mathrm{~min}$. Thereafter, the gel was incubated at $37^{\circ} \mathrm{C}$ for $24 \mathrm{~h}$ in conditioned fluid $(50 \mathrm{mmol} / 1$ Tris- $\mathrm{HCl}, 5 \mathrm{mmol} / 1$ $\mathrm{CaCl}_{2}, 1 \mathrm{mmol} / 1 \mathrm{ZnCl}_{2}, 0.02 \%$ Brij $35 \mathrm{pH}$ 7.6). Then stained with Coomassie R250 and destained with methanol and acetic acid. Gelatinolytic activities were performed as clear zones against dark blue background. The images were photographed with a PM-CBAD image system. Bands were analyzed using ImageJ v1.43 software.

Statistical analysis. The data were representative of at least 3 independent experiments. It was recorded as mean \pm SD (standard deviation) and evaluated by SPSS13.0 (SPSS, Inc., Chicago, IL, USA). Differences between groups were analyzed by one-way analysis of variance (ANOVA) or Student's unpaired t-test. Tests of homogeneity of variances were run before post hoc multiple comparisons. With equal variances the LSD-test was used, or else the Games-Howell test would be used. $\mathrm{P}<0.05$ was considered to indicate a statistically significant result.

\section{Results}

pLV-TGF $\beta$ transfected cells were under an EMT process that could be reversed by SB203580. Cells transfected with pLV-TGF $\beta$ showed a more mesenchymal morphology compared with those transfected with empty vector. The appearance of cells switched from an astrocytic shape to a fibroblastic one, which could be observed under a fluorescence microscope (Fig. 1). With the addition of SB203580, cells had a less slender shape and regained their 'envelope synapses'. To explore the gene and protein expression of the cells, we conducted RT-PCR, western blot analysis and ELISA. RT-PCR results (Fig. 2A and B) showed that: $\operatorname{smad} 2$ transcript in $\mathrm{pLV}-\mathrm{TGF} \beta$ group was significantly higher than that in $\mathrm{NC}$ group $(\mathrm{P}<0.001)$, but was almost at the same level with that in pLV-TGF $\beta+$ SB203580 group $(\mathrm{P}=0.349)$; $\mathrm{p} 38$ transcript in $\mathrm{pLV}-\mathrm{TGF} \beta$ group was significantly higher than that in NC group $(\mathrm{P}<0.001)$, but was almost at the same level with that in pLV-TGF $\beta+$ SB203580 group $(\mathrm{P}=0.421)$; TGF- $\beta$ transcript in $\mathrm{pLV}-\mathrm{TGF} \beta$ group was significantly higher than that in $\mathrm{NC}$ group $(\mathrm{P}<0.001)$, but was almost at the same level with that in pLV-TGF $\beta+$ SB203580 group ( $\mathrm{P}=0.387)$; $\mathrm{E}$-cadherin transcript in $\mathrm{pLV}-\mathrm{TGF} \beta$ group was significantly lower than that in $\mathrm{NC}$ group $(\mathrm{P}=0.001)$ and pLV-TGF $\beta+$ SB203580 group $(\mathrm{P}<0.001)$, and E-cadherin transcript in $\mathrm{pLV}-\mathrm{TGF} \beta+\mathrm{SB} 203580$ group was significantly higher than that in $\mathrm{NC}$ group $(\mathrm{P}<0.001)$; $\mathrm{N}$-cadherin transcript in pLV-TGF $\beta$ group was significantly higher than that in $\mathrm{NC}$ group $(\mathrm{P}<0.001)$ and $\mathrm{pLV}-\mathrm{TGF} \beta+\mathrm{SB} 203580$ group $(\mathrm{P}<0.001)$, but $\mathrm{N}$-cadherin transcript in pLV-TGF $\beta+\mathrm{SB} 203580$ group was significantly lower than that in NC group $(\mathrm{P}=0.024)$; MT1-MMP transcript in pLV-TGF $\beta$ group was significantly higher than that in $\mathrm{NC}$ group $(\mathrm{P}<0.001)$, and was almost at the same level with that in pLV-TGF $\beta+\mathrm{SB} 203580$ group $(\mathrm{P}=0.180)$. Western blot results (Fig. 2C and D) showed that p-smad2 expression in pLV-TGF $\beta$ group was significantly higher than that in NC group $(\mathrm{P}<0.001)$, but was almost at the same level with that in pLV-TGF $\beta+$ SB203580 group $(\mathrm{P}=0.132)$; $\operatorname{smad} 2$ expression in $\mathrm{pLV}-\mathrm{TGF} \beta$ group was significantly higher than that in $\mathrm{NC}$ group $(\mathrm{P}=0.004)$, but was almost at the same level with that in $\mathrm{pLV}-\mathrm{TGF} \beta+\mathrm{SB} 203580$ group $(\mathrm{P}=0.863)$; $\mathrm{p}-\mathrm{p} 38$ expression in $\mathrm{pLV}-\mathrm{TGF} \beta$ group was significantly higher than that in $\mathrm{NC}$ group $(\mathrm{P}=0.002)$ and $\mathrm{pLV}-\mathrm{TGF} \beta+\mathrm{SB} 203580$ group $(\mathrm{P}=0.001)$, and $\mathrm{p}-\mathrm{p} 38$ expression in $\mathrm{pLV}-\mathrm{TGF} \beta+\mathrm{SB} 203580$ 


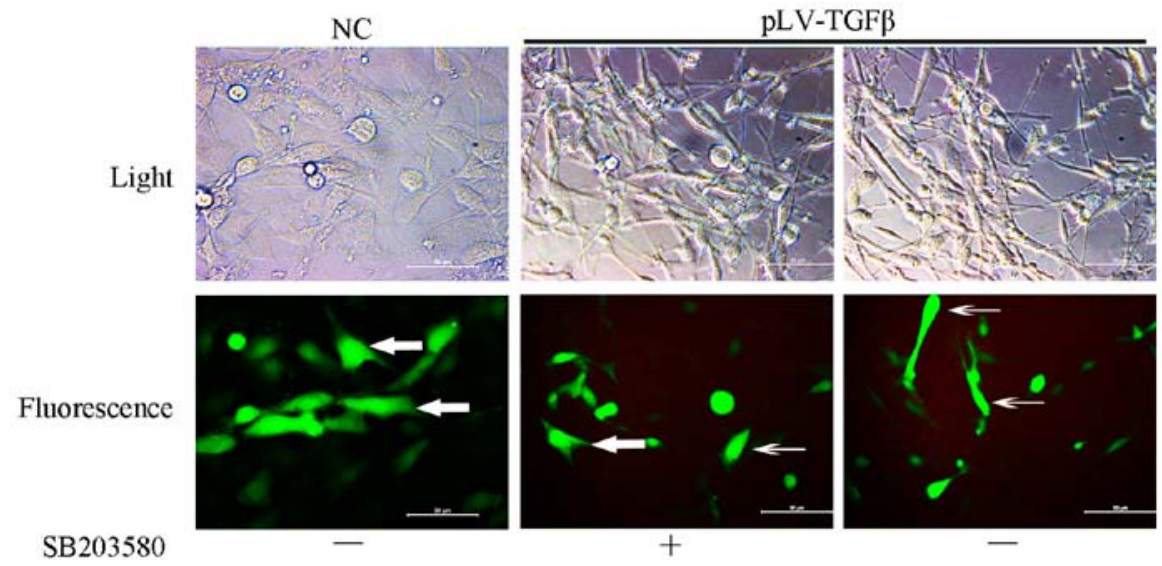

Figure 1. Morphology of SHG44 glioma cells in different groups. The phenotype of cells transformed from astrocytic (NC group) to fibroblastic (pLV-TGF $\beta$ group), but it could be reversed when cells were cultured with the addition of $10 \mu \mathrm{M} \mathrm{SB} 203580$ (pLV-TGF $\beta+\mathrm{SB} 203580$ group). Scale bar, $50 \mu \mathrm{m}$. Broad arrow, star-shape cell; narrow arrow, spindle-shape cell.
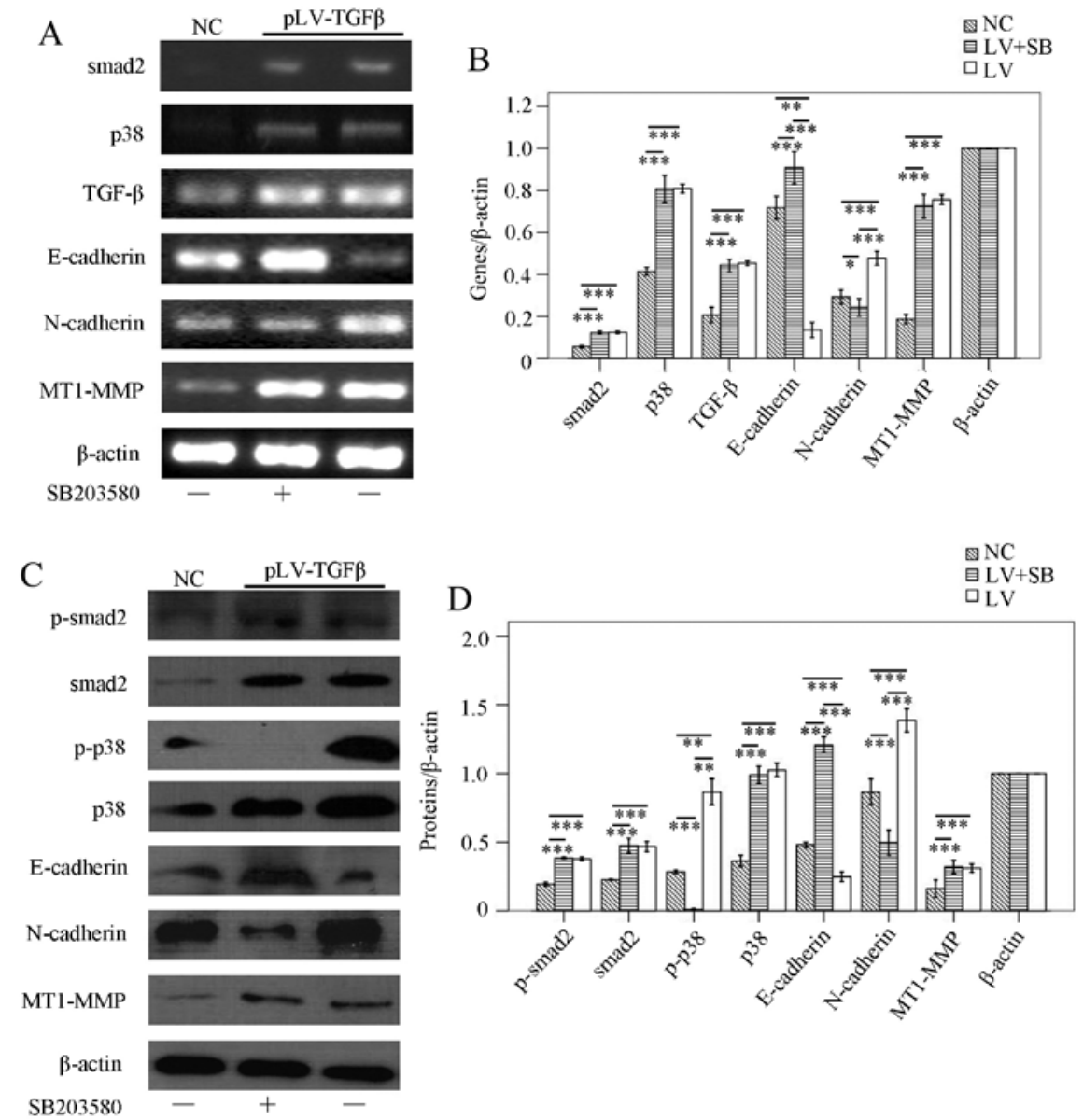

SB203580
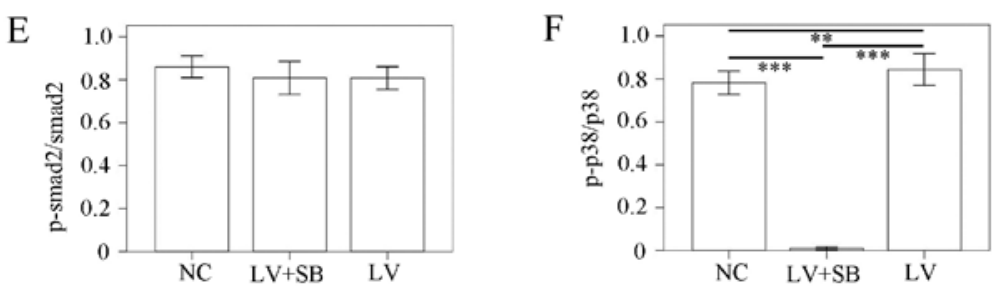

Figure 2. Gene transcripts and protein expression in the three groups of cells. (A and B) RT-PCR assays. Upregulation of smad2, p38, TGF- $\beta$, N-cadherin, MT1-MMP and downregulation of E-cadherin were observed when SHG44 cells were transfected with pLV-TGF $\beta$. SB203580 inhibited the transcript of $\mathrm{N}$-cadherin, while enhanced the transcript of E-cadherin. (C and D) Western blot assays. Upregulation of p-smad2, smad2, p-p38, p38, N-cadherin, MT1-MMP and downregulation of E-cadherin were observed when SHG44 cells were transfected with pLV-TGF $\beta$. SB203580 inhibited the expression of p-p38 and $\mathrm{N}$-cadherin, while enhanced the expression of E-cadherin. (E) The phosphorylation of smad2 had no differences among groups. (F) The phosphorylation of p38 was inhibited by SB203580. $\beta$-actin served as internal control. ${ }^{*} \mathrm{P}<0.05,{ }^{* *} \mathrm{P}<0.01,{ }^{* * *} \mathrm{P}<0.001$. 

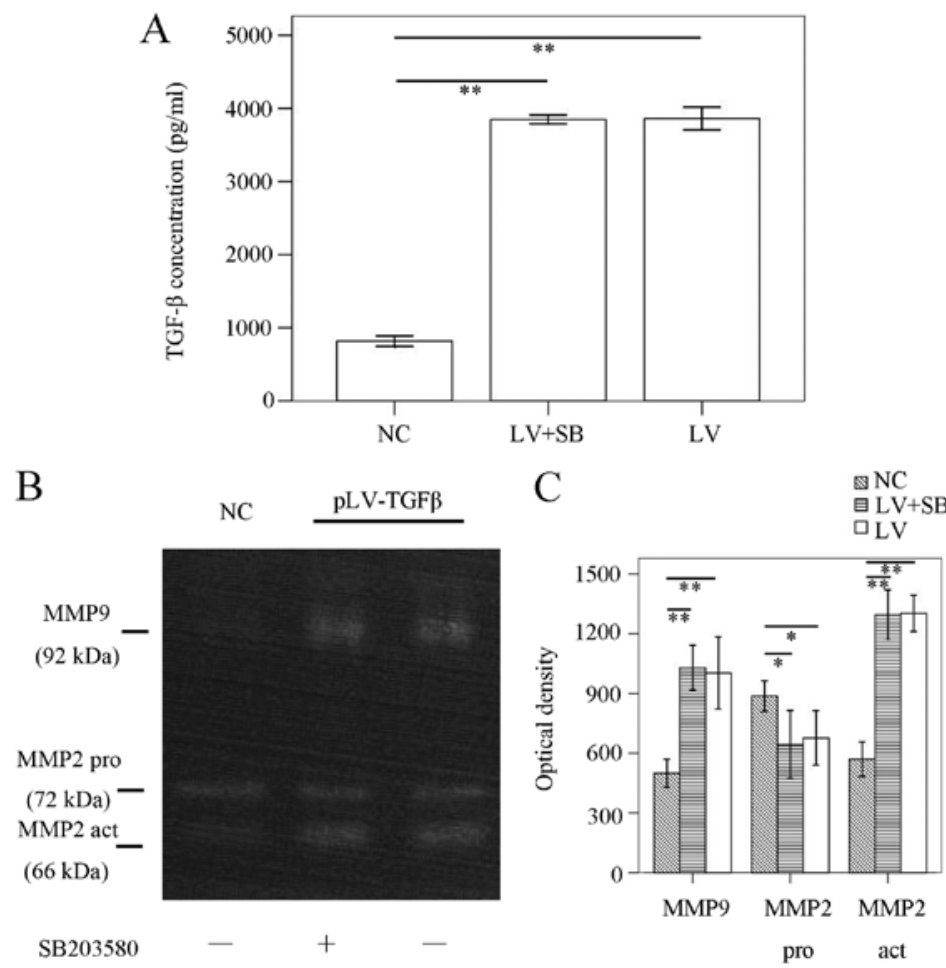

Figure 3. TGF- $\beta$ ELISA and MMP zymogram. (A) ELISA assays. TGF- $\beta$ concentration in the supernatant was elevated when SHG44 cells were transfected with pLV-TGFv. SB203580 did not affect the secretion of TGF- $\beta$. (B and C) MMP zymogram. MMP2/9 activation was elevated in pLV-TGF $\beta$ group, but was not affected by adding SB203580. ${ }^{*} \mathrm{P}<0.01,{ }^{* *} \mathrm{P}<0.001$.

A
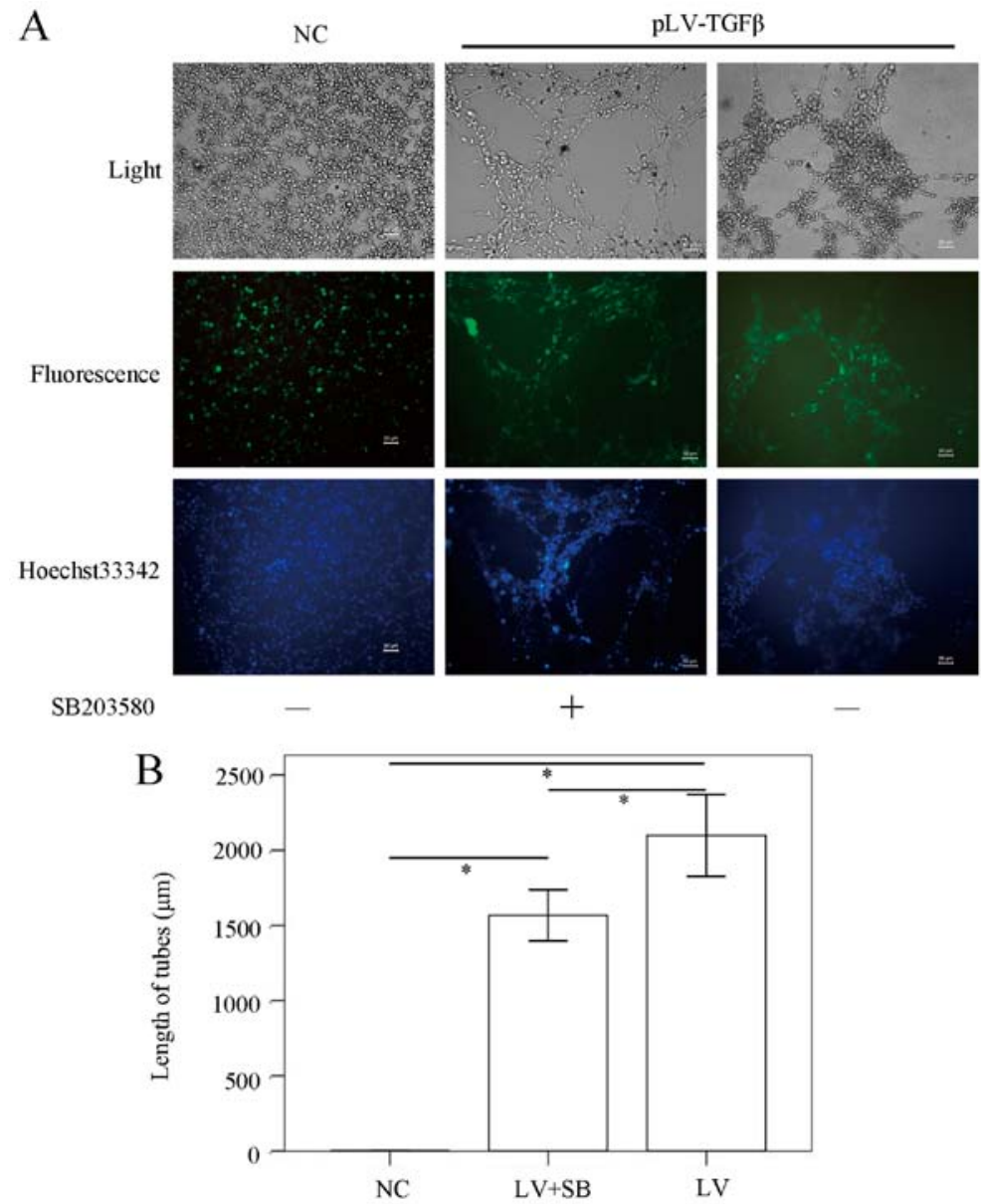

Figure 4. In vitro VM formation assays. (A) SHG44 cells were able to form VM tubes when transfected with pLV-TGF $\beta$. Their capability of VM formation could be impaired by SB203580. Scale bar, $50 \mu \mathrm{m}$. (B) Comparison of length of VM tubes among groups. ${ }^{*} \mathrm{P}<0.001$. 
A
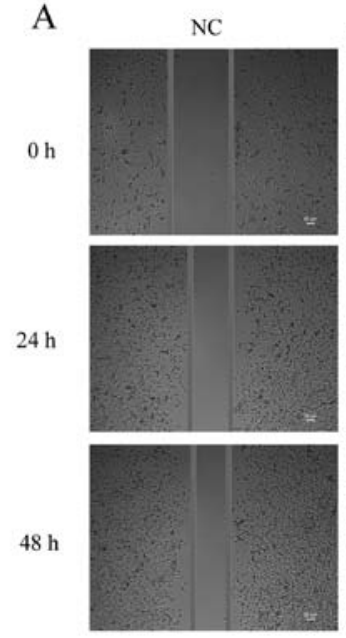

SB203580

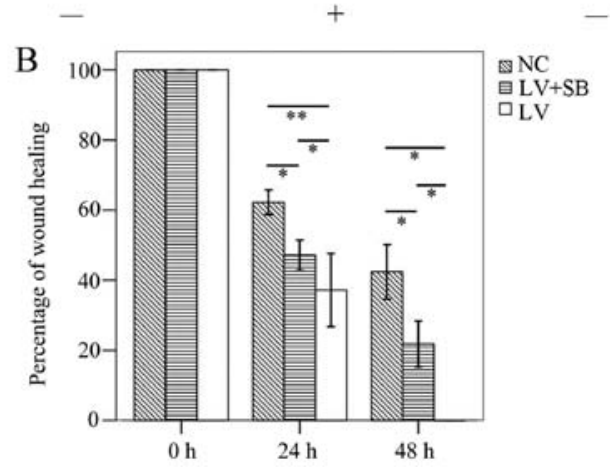

Figure 5. Wound healing assays. (A) Migration of SHG44 cells increased when cells were transfected with pLV-TGF $\beta$, and it could be impaired by SB203580. Scale bar, $50 \mu \mathrm{m}$. (B) Comparison of wound healing percentage among groups. ${ }^{*} \mathrm{P}<0.01,{ }^{* *} \mathrm{P}<0.001$.

group was significantly lower than that in NC group $(\mathrm{P}<0.001)$; $\mathrm{p} 38$ expression in $\mathrm{pLV}-\mathrm{TGF} \beta$ group was significantly higher than that in NC group $(\mathrm{P}<0.001)$, but was almost at the same level with that in pLV-TGF $\beta+$ SB203580 group $(\mathrm{P}=0.089)$; $\mathrm{E}$-cadherin expression in $\mathrm{pLV}-\mathrm{TGF} \beta$ group was significantly lower than that in $\mathrm{NC}$ group $(\mathrm{P}=0.001)$ and pLV-TGF $\beta+$ SB203580 group $(\mathrm{P}<0.001)$, and E-cadherin expression in $\mathrm{pLV}-\mathrm{TGF} \beta+\mathrm{SB} 203580$ group was significantly higher than that in $\mathrm{NC}$ group $(\mathrm{P}<0.001) ; \mathrm{N}$-cadherin expression in $\mathrm{pLV}-\mathrm{TGF} \beta$ group was significantly higher than that in NC group $(\mathrm{P}<0.001)$ and $\mathrm{pLV}-\mathrm{TGF} \beta+\mathrm{SB} 203580$ group $(\mathrm{P}<0.001)$, and $\mathrm{N}$-cadherin expression in $\mathrm{pLV}-\mathrm{TGF} \beta+\mathrm{SB} 203580$ group was significantly lower than that in $\mathrm{NC}$ group $(\mathrm{P}<0.001)$; MT1-MMP expression in $\mathrm{pLV-TGF} \beta$ group was significantly higher than that in $\mathrm{NC}$ group $(\mathrm{P}=0.030)$, and was almost at the same level with that in $\mathrm{pLV}-\mathrm{TGF} \beta+\mathrm{SB} 203580$ group $(\mathrm{P}=0.569)$. As the smad2 phosphorylation is a reliable indicator of downstream TGF- $\beta$ signaling, we compared the ratio of $p$-smad 2 to $\operatorname{smad} 2$ among groups. The extent of phosphorylation of smad2 (Fig. 2E) had no difference between pLV-TGF $\beta$ group and pLV-TGF $\beta+S B 203580$ group $(\mathrm{P}=0.988)$. The extent of phosphorylation of p38 (Fig. 2F) in pLV-TGF $\beta$ group was much higher than that in pLV-TGF $\beta+\mathrm{SB} 203580$ group $(\mathrm{P}<0.001)$. ELISA results (Fig. $3 \mathrm{~A}$ ) showed that TGF- $\beta$ concentration in pLV-TGF $\beta$ group was significantly higher than that in $\mathrm{NC}$ group $(\mathrm{P}<0.001)$, but was almost at the same level with that in
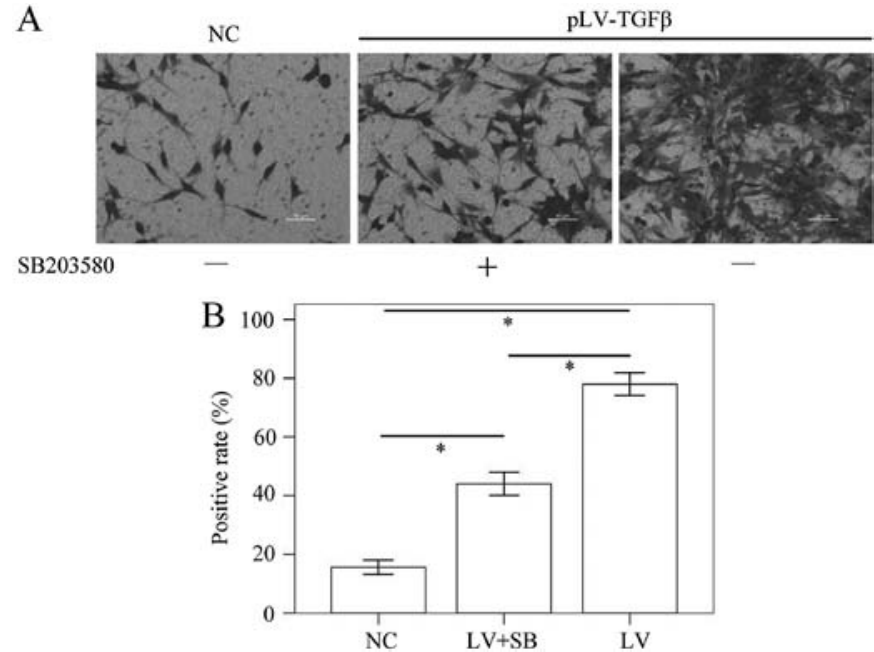

Figure 6. Transwell assays. (A) Invasion of SHG44 cells increased when cells were transfected with pLV-TGF $\beta$, and it could be impaired by SB203580. Scale bar, $50 \mu \mathrm{m}$. (B) Comparison of positive stained area among groups. ${ }^{*} \mathrm{P}<0.001$.

pLV-TGF $\beta+$ SB203580 group ( $\mathrm{P}=0.752)$. To detect the MMPs activation of the cells, we conducted gelatin zymography. The results (Fig. 3B and C) showed that there was no difference between pLV-TGF $\beta$ group and pLV-TGF $\beta+$ SB203580 group in MMP9 activity $(\mathrm{P}=0.555)$ or MMP2 activity $(\mathrm{P}=0.850)$.

The in vitro VM formation, cell migration, invasion and proliferation of $p L V$-TGF $\beta$ transfected cells were inhibited by SB203580. To explore the effect of SB203580 on biological properties of pLV-TGF $\beta$ transfected cells, we conducted in vitro $\mathrm{VM}$ formation assays, wound healing assays, Transwell assays and CCK-8 assays. The in vitro VM formation assay results (Fig. 4) showed that the mean length of VM tubes in pLV-TGF $\beta$ group was significantly longer than that in NC group $(\mathrm{P}<0.001)$ and $\mathrm{pLV}-\mathrm{TGF} \beta+\mathrm{SB} 203580$ group $(\mathrm{P}=0.005)$, and the mean length of VM tubes in pLV-TGF $\beta+$ SB203580 group was significantly longer than that in $\mathrm{NC}$ group $(\mathrm{P}<0.001)$. The wound healing assay results (Fig. 5) showed that the mean gap in $\mathrm{pLV}-\mathrm{TGF} \beta$ group was significantly smaller than that in $\mathrm{NC}$ group $(\mathrm{P}<0.001 / \mathrm{P}=0.003)$ or $\mathrm{pLV}-\mathrm{TGF} \beta+\mathrm{SB} 203580$ group $(\mathrm{P}=0.004 / \mathrm{P}=0.009)$ at $24 / 48 \mathrm{~h}$, and the mean gap in pLV-TGF $\beta+$ SB203580 group was significantly smaller than that in NC group $(\mathrm{P}=0.001 / \mathrm{P}=0.002)$ at $24 / 48 \mathrm{~h}$. The wound was actually closed at $48 \mathrm{~h}$ in pLV-TGF $\beta$ group. The Transwell assay results (Fig. 6) showed that the mean stained area in pLV-TGF $\beta$ group was significantly larger than that in NC group $(\mathrm{P}<0.001)$ and $\mathrm{pLV}-\mathrm{TGF} \beta+\mathrm{SB} 203580$ group $(\mathrm{P}<0.001)$, and the mean stained area in pLV-TGF $\beta+\mathrm{SB} 203580$ group was significantly larger than that in $\mathrm{NC}$ group $(\mathrm{P}<0.001)$. The CCK-8 assay results (Fig. 7) showed that the optical density from the 3 rd day to the 7 th day in pLV-TGF $\beta$ group was significantly higher than that in NC group; the optical density from the 3rd day to the 7th day in pLV-TGF $\beta+$ SB203580 group was significantly lower than that in $\mathrm{pLV-TGF} \beta$ group.

The volume and VM density of the xenograft formed by $p L V$-TGF $\beta$ transfected cells were inhibited by SB203580. The model of SHG44 tumor-bearing nude mouse was successfully 


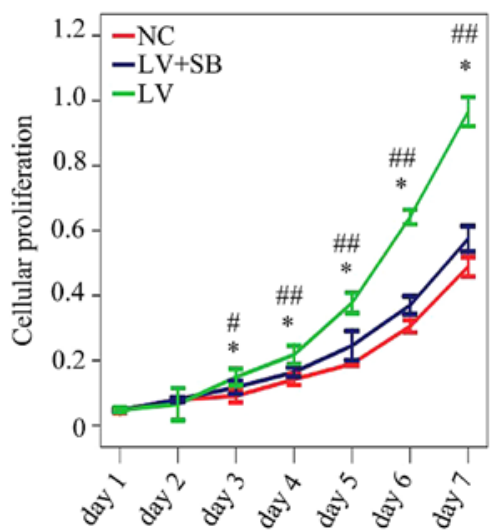

Figure 7. CCK-8 assays. Cell proliferation of SHG44 cells increased when cells were transfected with pLV-TGF $\beta$, and it could be impaired by SB203580. "pLV-TGF $\beta$ vs. NC P<0.001; "pLV-TGF $\beta+$ SB203580 vs. pLV-TGF $\beta$ P $<0.01$; \#\#/\#V-TGF $\beta+$ SB203580 vs. pLV-TGF $\beta$ P $<0.001$.

A

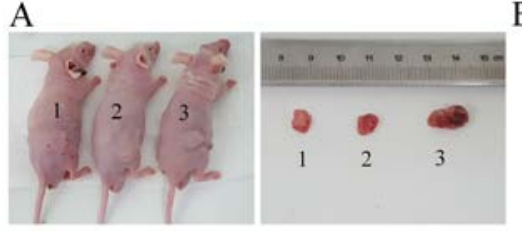

$\mathrm{C}$

$\mathrm{NC}$

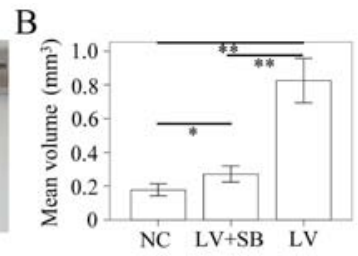

pLV-TGF $\beta$

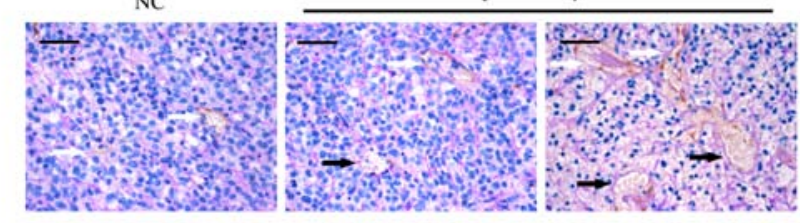

SB203580
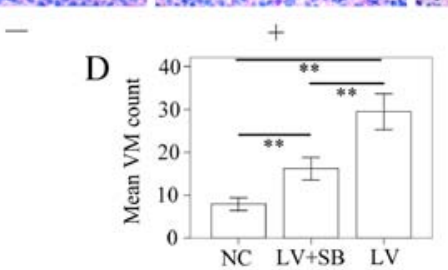

Figure 8. Tumor volume comparison and in vivo VM density assays. (A and B) Tumor volume comparison. Tumor volume increased in the group of cells transfected with pLV-TGF $\beta$, and shrunken by adding SB203580. 1, NC; 2 , pLV-TGF $\beta+S B 203580 ; 3$, pLV-TGF $\beta$. (C and D) In vivo VM density assays. CD34 (brown)-PAS (magenta) dual staining was used to distinguish between endothelial vessel (black arrows) and VM (white arrows). The yellow dots within the vessels or VM are erythrocytes. The amount of VM tubes increased in pLV-TGF $\beta$ group, and it could be reduced by adding SB203580. Scale bar, $50 \mu \mathrm{m} .{ }^{*} \mathrm{P}<0.01,{ }^{* *} \mathrm{P}<0.001$.

established. The tumor volume was detected using a vernier caliper according to the formula: $\pi / 6 \mathrm{x} \mathrm{W}^{2} \mathrm{x} \mathrm{L}$. The $\mathrm{L}$ stands for the long axis, and the $\mathrm{W}$ for the short axis. The results (Fig. 8A and B) showed that the mean volume of tumor in pLV-TGF $\beta$ group was significantly larger than that in $\mathrm{NC}$ group $(\mathrm{P}<0.001)$ and $\mathrm{pLV}-\mathrm{TGF} \beta+\mathrm{SB} 203580$ group $(\mathrm{P}<0.001)$, and the mean volume of tumor in pLV-TGF $\beta+\mathrm{SB} 203580$ group was significantly larger than that in $\mathrm{NC}$ group $(\mathrm{P}=0.005)$. We also assessed the capability of tumor cells to form VM in vivo by counting the CD34-negative vessels as previously described. The results (Fig. 8C and D) showed that the amount of VM tubes in pLV-TGF $\beta$ group was significantly more than that in NC

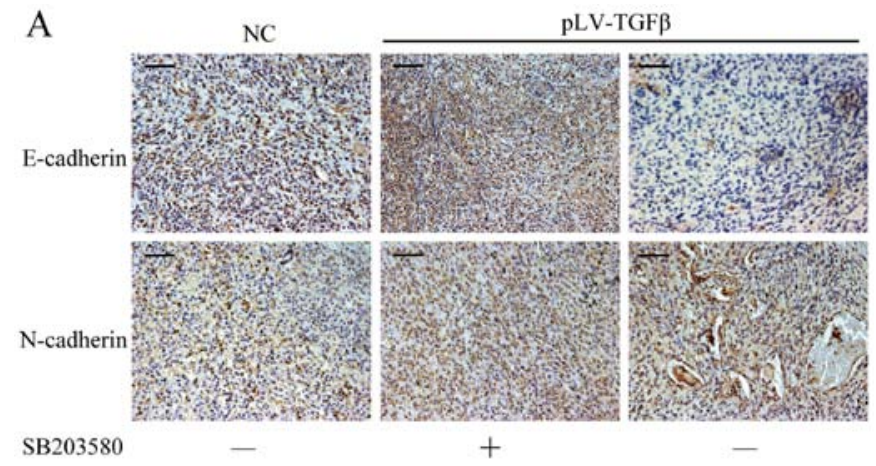

SB203580

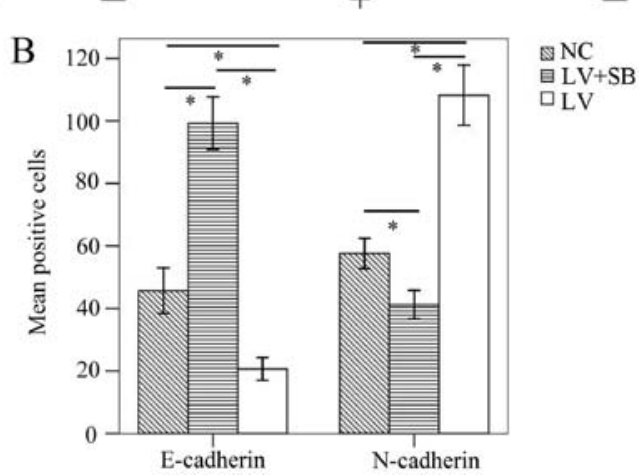

Figure 9. Immunohistochemistry assays. (A) Downregulation of E-cadherin and upregulation of $\mathrm{N}$-cadherin were found in pLV-TGF $\beta$ group. SB203580 could reverse the EMT by upregulating E-cadherin expression and downregulating $\mathrm{N}$-cadherin expression. Scale bar, $200 \mu \mathrm{m}$. (B) Comparison of mean positive cells among groups. ${ }^{*} \mathrm{P}<0.001$.

group $(\mathrm{P}<0.001)$ and $\mathrm{pLV}-\mathrm{TGF} \beta+\mathrm{SB} 203580$ group $(\mathrm{P}<0.001)$, and the amount of VM tubes in pLV-TGF $\beta+\mathrm{SB} 203580$ group was significantly more than that in $\mathrm{NC}$ group $(\mathrm{P}<0.001)$.

The MT1-MMP/LAMC2 signaling pathways were not affected by EMT reversion induced by SB203580. To determine the EMT effect of TGF- $\beta$ overexpression and reversal effect of SB203580, we carried out immunohistochemistry assay to detect the expression of E-cadherin and $\mathrm{N}$-cadherin. The results (Fig. 9) showed that E-cadherin-positive cells in pLV-TGF $\beta$ group were significantly less than those in NC group $(\mathrm{P}<0.001)$ and $\mathrm{pLV}-\mathrm{TGF} \beta+\mathrm{SB} 203580$ group $(\mathrm{P}<0.001)$, and E-cadherin-positive cells in pLV-TGF $\beta+$ SB203580 group were significantly more than those in NC group $(\mathrm{P}<0.001) ; \mathrm{N}$-cadherin-positive cells in $\mathrm{pLV}$-TGF $\beta$ group were significantly more than those in $\mathrm{NC}$ group $(\mathrm{P}<0.001)$ and pLV-TGF $\beta+$ SB203580 group $(\mathrm{P}<0.001)$, and N-cadherinpositive cells in $\mathrm{pLV}-\mathrm{TGF} \beta+\mathrm{SB} 203580$ group were significantly less than those in NC group $(\mathrm{P}<0.001)$. RT-PCR and western blot analysis were employed to detect the gene transcripts and protein expression of $\mathrm{p} 38, \mathrm{MT} 1-\mathrm{MMP}$ and LAMC2. The RT-PCR results (Fig. 10A and B) showed that p38 transcript in pLV-TGF $\beta$ group was significantly higher than that in NC group $(\mathrm{P}<0.001)$, but was almost at the same level with that in pLV-TGF $\beta+$ SB203580 group ( $\mathrm{P}=0.328)$; $M$ T1-MMP transcript in $\mathrm{pLV}-\mathrm{TGF} \beta$ group was significantly higher than that in NC group $(\mathrm{P}=0.002)$, and was almost at the same level with that in $\mathrm{pLV-TGF} \beta+\mathrm{SB} 203580$ group $(\mathrm{P}=0.562)$; LAMC2 transcript had no difference among groups $(\mathrm{P}=0.648)$. In the western blot assay, LAMC2 was detected to be cleaved into LAMC2' partly. The results (Fig. 10C and D) showed that p-smad2 

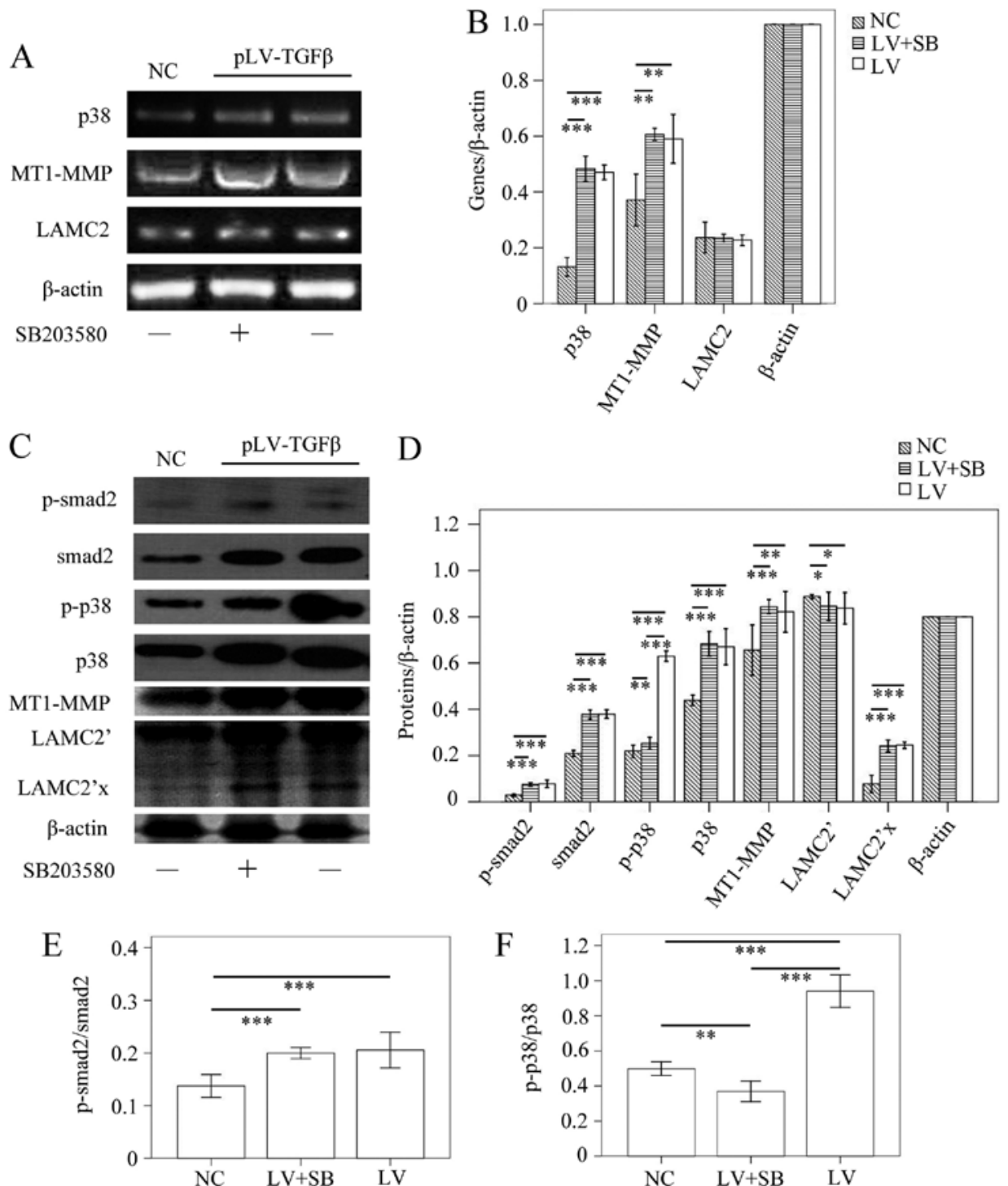

Figure 10. Gene transcripts and protein expression in the three groups of xenografts. (A and B) RT-PCR assays. Upregulation of p38 and MT1-MMP were observed in pLV-TGF $\beta$ group. SB203580 inhibited the expression of p38, but had no influence on expression of MT1-MMP and LAMC2. (C and D) Western blot assays. Upregulation of p38, MT1-MMP and LAMC2 were observed in pLV-TGF 3 group. SB203580 inhibited the expression of p38, but had no influence on MT1-MMP and LAMC2' expression. (E) The phosphorylation of smad2 was not affected by SB203580. (F) The phosphorylation of p38 was inhibited by SB203580. $\beta$-actin served as internal control. ${ }^{*} \mathrm{P}<0.05,{ }^{* *} \mathrm{P}<0.01,{ }^{* * *} \mathrm{P}<0.001$.

expression in pLV-TGF $\beta$ group was significantly higher than that in $\mathrm{NC}$ group $(\mathrm{P}<0.001)$, but was almost at the same level with that in pLV-TGF $\beta+\mathrm{SB} 203580$ group $(\mathrm{P}=0.536)$; $\operatorname{smad} 2$ expression in $\mathrm{pLV}-\mathrm{TGF} \beta$ group was significantly higher than that in $\mathrm{NC}$ group $(\mathrm{P}<0.001)$, but was almost at the same level with that in $\mathrm{pLV}-\mathrm{TGF} \beta+\mathrm{SB} 203580$ group $(\mathrm{P}=0.864)$; $\mathrm{p}-\mathrm{p} 38$ expression in $\mathrm{pLV}-\mathrm{TGF} \beta$ group was significantly higher than that in $\mathrm{NC}$ group $(\mathrm{P}<0.001)$ and $\mathrm{pLV}-\mathrm{TGF} \beta+\mathrm{SB} 203580$ group $(\mathrm{P}<0.001)$; $\mathrm{p}-\mathrm{p} 38$ expression in $\mathrm{pLV}-\mathrm{TGF} \beta+\mathrm{SB} 203580$ group was significantly higher than that in $\mathrm{NC}$ group $(\mathrm{P}=0.006)$; p38 expression in pLV-TGF $\beta$ group was significantly higher than that in $\mathrm{NC}$ group $(\mathrm{P}<0.001)$, but was almost at the same level with that in $\mathrm{pLV}-\mathrm{TGF} \beta+\mathrm{SB} 203580$ group $(\mathrm{P}=0.501)$; MT1-MMP expression in pLV-TGF $\beta$ group was significantly higher than that in $\mathrm{NC}$ group $(\mathrm{P}<0.001)$, and was almost at the same level with that in $\mathrm{pLV}-\mathrm{TGF} \beta+\mathrm{SB} 203580$ group $(\mathrm{P}=0.105)$; LAMC2' expression in either $\mathrm{pLV}-\mathrm{TGF} \beta$ group or pLV-TGF $\beta+$ SB203580 group was significantly lower than that in $\mathrm{NC}$ group $(\mathrm{P}=0.040 / \mathrm{P}=0.026)$; LAMC2' expression in pLV-TGF $\beta$ group and $\mathrm{pLV}-\mathrm{TGF} \beta+\mathrm{SB} 203580$ group were almost at the same level $(\mathrm{P}=0.744)$; LAMC2' $\mathrm{x}$ expression in either $\mathrm{pLV-TGF} \beta$ group or $\mathrm{pLV}-\mathrm{TGF} \beta+\mathrm{SB} 203580$ group was significantly higher than that in $\mathrm{NC}$ group $(\mathrm{P}<0.001)$; LAMC2' $\mathrm{x}$ expression in $\mathrm{pLV}-\mathrm{TGF} \beta$ group and $\mathrm{pLV}-\mathrm{TGF} \beta+\mathrm{SB} 203580$ group were almost at the same level $(\mathrm{P}=0.512)$. The extent of phosphorylation of smad2 (Fig. 10E) had no difference between pLV-TGF $\beta$ group and pLV-TGF $\beta+\mathrm{SB} 203580$ group $(\mathrm{P}=0.503)$. The extent of phosphorylation of p38 (Fig. 10F) in pLV-TGF $\beta$ group was much higher than that in pLV-TGF $\beta+$ SB203580 group $(\mathrm{P}<0.001)$.

\section{Discussion}

Since VM was known as a supplemental blood supply system in tumor, anti-angiogenic therapies should target both endothelial neovessels and VM. In recent years, researchers are 
increasingly concerned about frontier of anti-angiogenic therapies and interested in a new concept, i.e. vascular normalization. Vascular normalization means that anti-angiogenic treatment merely affects the immature vasculature and leaves the mature vessels unaltered (28). It is thought to interrupt the growth of immature vessels and a subsequent increase in tumor hypoxia (29). In order to achieve vascular normalization, several potential targets besides anti-VEGF therapy need to co-exist, including blockage of TGF- $\beta$ signaling (30). Considering that our former study had revealed that the blockage of TGF- $\beta$ could impair VM formation in malignant glioma (24), we suggested that anti-VM treatment by blocking TGF- $\beta$ signaling might be a part of vascular normalization. Furthermore, the detailed mechanism of VM formation induced by TGF- $\beta$ awaited investigation.

Both the EMT signaling pathways and VM played important roles in tumor metastasis and invasion. However, few studies exist on the relationship between them. TGF- $\beta$ was suggested to be a major inducer of EMT $(31,32)$, with downstream signaling mainly involving smad and non-smad pathways. The non-smad pathways were composed of PI3K/Akt, NF-kappaB, FAK and p38/MAPK sub-pathways according to the research by Morrison et al (33). The final effect of these signaling pathways would result in downregulation of epithelial markers (e.g. E-cadherin and zonula occludens-1) and upregulation of mesenchymal markers (e.g. N-cadherin and vimentin), which were considered to be universal features of EMT (34). Besides, TGF- $\beta$ inhibition was found to weaken the capability of VM formation in malignant glioma cell line (24). Hence, we wished to investigate whether TGF- $\beta$ could be a connection between EMT and VM.

To clarify this, we stably upregulated the TGF- $\beta$ expression in a less aggressive glioma cell line SHG44. It was found that the TGF- $\beta$-induced p38 signaling pathways were activated, leading to downregulation of E-cadherin and upregulation of $\mathrm{N}$-cadherin. With the genetical variation, the morphology and biological behavior of SHG44 cells changed, which became more mesenchymal and aggressive according to the results of cell migration/invasion assays and tube formation assays. Besides, TGF- $\beta$ also stimulated SHG44 cells to proliferate according to the CCK-8 assays. It was consistent with the theory of TGF- $\beta$ paradox rather than inhibiting cell proliferation in normal tissue, TGF- $\beta$ promotes tumor growth and progression in cancer tissue (35). To investigate the possible mechanism, we detected the gene/protein expression and MMP zymogram of cells in different groups. On the one hand, TGF- $\beta$ activated p38/Smad2 sub-pathways, resulting in EMT occurrence. On the other hand, TGF- $\beta$ elevated MT1-MMP expression and MMP2/9 activation. These results were consistent with the study by Zhao et al (36) that TGF- $\beta / \mathrm{p} 38 / \mathrm{Smad} 2$ pathway played a key role in growth and metastasis of glioma cells. However, the results of tube formation assays seemed to contradict with our previous report that SHG44 could not form $\mathrm{VM}$ in Matrigel-coated wells even when we added exogenous TGF- $\beta$ into the culture medium (24). We speculated that the capability of VM formation in pLV-TGF $\beta$ transfected SHG44 cells originated from the long-term effect of elevated TGF- $\beta$ in autocrine manner. Adding exogenous cellular factors into medium in a short period might change the transcriptional level, but it might not affect the biological behavior of cells.
Besides, we also noted that long-term effect of TGF- $\beta$ upregulation increased the transcripts of p38 and smad2. As most studies had only considered the phosphorylation level of TGF- $\beta$ towards its downstream signaling, the exact mechanism was still uncertain and needs further investigation. In the future, we intend to silence TGF- $\beta$ transcript via RNAi technology to see if $\mathrm{p} 38$ and $\operatorname{smad} 2$ could be influenced on the transcriptional level.

In animal tests, stable overexpression was achieved of TGF- $\beta$ at least in one month when the pLV-TGF $\beta$ transfected SHG44 cells were injected subcutaneously into the nude mice. This enabled the in vivo EMT to occur. Similar to the in vitro tests, the in vivo capability of VM formation was also enhanced, thereby providing enough nutrition, probably partly resulting in larger volume of tumors. These findings were consistent with the others that low expression of TGF- $\beta$ helped to control cell migration, invasion and volume growth of the tumor $(37,38)$. Thus, the TGF- $\beta$-induced VM formation might play an important role in tumor-initiating at the first stage. Furthermore, TGF- $\beta$-upregulated xenografts performed downregulation of E-cadherin, upregulation of N-cadherin, p38, smad2 and MT1-MMP. The upregulation of MT1-MMP increased the LAMC2 cleavage, which might be responsible for the enhanced capability of VM formation in vivo.

On the basis of the in vitro and in vivo consequences above, it was suggested that TGF- $\beta$ had positive effects on inducing EMT and VM formation. However, it was not able to clarify whether the enhanced capability of VM formation resulted from the complex effects of both enhanced EMT and MT1-MMP-upregulation or just from MT1-MMP-upregulation alone. Since VM was discovered, the MMP-LAMC2 chain had been considered as the key signaling pathways that eventually resulted in VM network formation (4). As the key component and functional role of remodeling the extracellular matrix (ECM), LAMC2 was proteolytically cleaved by active MMP-2, which was activated by MT1-MMP (25). Blocking any of these components would lead to the collapse of VM. It was reported that the PI3K signaling pathways were responsible for the activation of MMP-LAMC2 chain in a tumor (39). We wondered if there were some other factors participating in the TGF- $\beta$-induced VM formation besides MT1-MMP. Thus, we tried to inhibit EMT in the TGF- $\beta$-induced VM model with minimized influence on MMP-LAMC2 chain by using SB203580, a specific p38/MAPK signaling inhibitor which was reported to block EMT process in tumor via non-smad signaling pathways $(40,41)$. It was employed to see if EMT played a role in VM formed by pLV-TGF $\beta$ transfected SHG44 glioma cells. The results showed that both in vitro and in vivo, capabilities of VM formation were impaired by EMT inhibition via non-smad signaling pathways. The main features of EMT inhibition by SB203580 were upregulation of E-cadherin and downregulation of $\mathrm{N}$-cadherin, which might originate from blockage of p38 phosphorylation. Additionally, EMT inhibition also caused reversion of cell shape transformation, cell migration and invasion, and enlarged volume of xenografts. These findings suggested that EMT might serve as a promoter of tumor cell plasticity contributing to VM formation. Furthermore, we noted that EMT inhibition via p38/MAPK (non-smad) signaling pathways could not fully collapse VM formation. Taken together, we attributed the possible mecha- 
nism to that EMT might be an alternative mechanism of VM formation in epithelial tumor different from the mesenchymal tumor which depend more on remodeling of ECM. Therefore, TGF- $\beta$-induced VM formation in glioma might be due to the common effects of elevated cell plasticity caused by EMT and remodeled ECM formed by activated MMP-LAMC2 chain. The present study provided a better understanding of the relationship between EMT and VM. More evidence should be collected in future investigations.

Although the current preliminary study indicated possible relationship between EMT and VM, major limitations should not be ignored. First of all, our observation was only based on one single cell line, which might be deficient in universality. In the further work, we might explore if the strong capability of VM formation in protogenetic highly malignant glioma is also resulted from combine effects of elevated cell plasticity caused by EMT and remodeled ECM. To address this, at least two different kinds of antagonist should be used to distinguish their exact effects. However, it would be disturbed in animal tests until better plans be carried out. Secondly, the inhibition of p38 signaling pathways in the present study was carried out solely by using a p38 chemical inhibitor instead of siRNA or clustered regularly interspaced short palindromic repeats (CRISPR). It might be able to fully suppress certain target expression by gene silence technology. To date, several researchers have claimed that they established high efficient carriers for systemic delivery of small interfering RNA (siRNA) to solid tumors $(42,43)$. Based on these new technologies, we would be able to achieve more convincing results in future studies.

In conclusion, the mechanism of TGF- $\beta$-induced VM formation in glioma might be due to the common effects of elevated cell plasticity caused by EMT and remodeled ECM formed by activated MMP-LAMC2 chain. EMT played an important role in TGF- $\beta$-induced VM formation, which might largely depend on improving tumor cell plasticity. EMT inhibition via $\mathrm{p} 38$ /MAPK signaling pathways would partly impair TGF- $\beta$-induced VM formation in glioma.

\section{Acknowledgements}

The present study was supported by the National Natural Science Foundation of China (grant no. 81302177).

\section{References}

1. Seystahl K and Weller M: Is there a world beyond bevacizumab in targeting angiogenesis in glioblastoma? Expert Opin Investig Drugs 21: 605-617, 2012.

2. Hillen $\mathrm{F}$ and Griffioen AW: Tumour vascularization: Sprouting angiogenesis and beyond. Cancer Metastasis Rev 26: 489-502, 2007.

3. Maniotis AJ, Folberg R, Hess A, Seftor EA, Gardner LM, Pe'er J, Trent JM, Meltzer PS and Hendrix MJ: Vascular channel formation by human melanoma cells in vivo and in vitro: Vasculogenic mimicry. Am J Pathol 155: 739-752, 1999.

4. Paulis YW, Soetekouw PM, Verheul HM, Tjan-Heijnen VC and Griffioen AW: Signalling pathways in vasculogenic mimicry. Biochim Biophys Acta 1806: 18-28, 2010.

5. van der Schaft DW, Hillen F, Pauwels P, Kirschmann DA, Castermans K, Egbrink MG, Tran MG, Sciot R, Hauben E, Hogendoorn PC, et al: Tumor cell plasticity in Ewing sarcoma, an alternative circulatory system stimulated by hypoxia. Cancer Res 65: 11520-11528, 2005.
6. van der Schaft DW, Seftor RE, Seftor EA, Hess AR, Gruman LM, Kirschmann DA, Yokoyama Y, Griffioen AW and Hendrix MJ: Effects of angiogenesis inhibitors on vascular network formation by human endothelial and melanoma cells. J Natl Cancer Inst 96: 1473-1477, 2004

7. Pàez-Ribes M, Allen E, Hudock J, Takeda T, Okuyama H, Viñals F, Inoue M, Bergers G, Hanahan D and Casanovas O: Antiangiogenic therapy elicits malignant progression of tumors to increased local invasion and distant metastasis. Cancer Cell 15: $220-231,2009$.

8. Folberg R and Maniotis AJ: Vasculogenic mimicry. APMIS 112: 508-525, 2004.

9. Chen YS and Chen ZP: Vasculogenic mimicry: A novel target for glioma therapy. Chin J Cancer 33: 74-79, 2014.

10. Yang Z, Sun B, Zhao X, Shao B, An J, Gu Q, Wang Y, Dong X, Zhang Y and Qiu Z: Erythropoietin and erythropoietin receptor in hepatocellular carcinoma: Correlation with vasculogenic mimicry and poor prognosis. Int J Clin Exp Pathol 8: 4033-4043, 2015.

11. Liu T, Sun B, Zhao X, Li Y, Gu Q, Dong X and Liu F: OCT4 expression and vasculogenic mimicry formation positively correlate with poor prognosis in human breast cancer. Int J Mol Sci 15: 19634-19649, 2014.

12. Wang SY, Ke YQ, Lu GH, Song ZH, Yu L, Xiao S, Sun XL, Jiang XD, Yang ZL and Hu CC: Vasculogenic mimicry is a prognostic factor for postoperative survival in patients with glioblastoma. J Neurooncol 112: 339-345, 2013.

13. Puisieux A, Brabletz T and Caramel J: Oncogenic roles of EMT-inducing transcription factors. Nat Cell Biol 16: 488-494, 2014.

14. Ping YF and Bian XW: Consice review: Contribution of cancer stem cells to neovascularization. Stem Cells 29: 888-894, 2011.

15. Wang W, Lin P, Sun B, Zhang S, Cai W, Han C, Li L, Lu H and Zhao X: Epithelial-mesenchymal transition regulated by EphA2 contributes to vasculogenic mimicry formation of head and neck squamous cell carcinoma. Biomed Res Int 2014: 803914, 2014.

16. Yang Z, Sun B, Li Y, Zhao X, Zhao X, Gu Q, An J, Dong X, Liu F and Wang Y: ZEB2 promotes vasculogenic mimicry by TGF- $\beta 1$ induced epithelial-to-mesenchymal transition in hepatocellular carcinoma. Exp Mol Pathol 98: 352-359, 2015.

17. Lee JM, Dedhar S, Kalluri R and Thompson EW: The epithelialmesenchymal transition: New insights in signaling, development, and disease. J Cell Biol 172: 973-981, 2006.

18. Kang H, Lee M and Jang SW: Celastrol inhibits TGF- $\beta 1$-induced epithelial-mesenchymal transition by inhibiting Snail and regulating E-cadherin expression. Biochem Biophys Res Commun 437: 550-556, 2013.

19. May CD, Sphyris N, Evans KW, Werden SJ, Guo W and Mani SA: Epithelial-mesenchymal transition and cancer stem cells: A dangerously dynamic duo in breast cancer progression. Breast Cancer Res 13: 202, 2011.

20. Mani SA, Guo W, Liao MJ, Eaton EN, Ayyanan A, Zhou AY, Brooks M, Reinhard F, Zhang CC, Shipitsin M, et al: The epithelial-mesenchymal transition generates cells with properties of stem cells. Cell 133: 704-715, 2008.

21. Lindsey S and Langhans SA: Cross talk of oncogenic signaling pathways during epithelial-mesenchymal transition. Front Oncol 4: 358, 2014.

22. Kang Y, Siegel PM, Shu W, Drobnjak M, Kakonen SM, CordónCardo C, Guise TA and Massagué J: A multigenic program mediating breast cancer metastasis to bone. Cancer Cell 3: 537-549, 2003.

23. Sánchez-Elsner T, Botella LM, Velasco B, Corbí A, Attisano L and Bernabéu C: Synergistic cooperation between hypoxia and transforming growth factor-beta pathways on human vascular endothelial growth factor gene expression. J Biol Chem 276: 38527-38535, 2001.

24. Ling G, Wang S, Song Z, Sun X, Liu Y, Jiang X, Cai Y, Du M and $\mathrm{Ke} Y$ : Transforming growth factor- $\beta$ is required for vasculogenic mimicry formation in glioma cell line U251MG. Cancer Biol Ther 12: 978-988, 2011.

25. Seftor RE, Seftor EA, Koshikawa N, Meltzer PS, Gardner LM, Bilban M, Stetler-Stevenson WG, Quaranta V and Hendrix MJ: Cooperative interactions of laminin 5 gamma2 chain, matrix metalloproteinase-2, and membrane type-1-matrix/metalloproteinase are required for mimicry of embryonic vasculogenesis by aggressive melanoma. Cancer Res 61: 6322-6327, 2001.

26. Yue WY and Chen ZP: Does vasculogenic mimicry exist in astrocytoma? J Histochem Cytochem 53: 997-1002, 2005.

27. Folberg R, Hendrix MJ and Maniotis AJ: Vasculogenic mimicry and tumor angiogenesis. Am J Pathol 156: 361-381, 2000. 
28. Jain RK: Normalization of tumor vasculature: An emerging concept in antiangiogenic therapy. Science 307: 58-62, 2005.

29. De Bock K, Cauwenberghs S and Carmeliet P: Vessel abnormalization: Another hallmark of cancer? Molecular mechanisms and therapeutic implications. Curr Opin Genet Dev 21: 73-79, 2011.

30. Dieterich LC, Mellberg S, Langenkamp E, Zhang L, Zieba A, Salomäki H, Teichert M, Huang H, Edqvist PH, Kraus T, et al: Transcriptional profiling of human glioblastoma vessels indicates a key role of VEGF-A and TGF $\beta 2$ in vascular abnormalization. J Pathol 228: 378-390, 2012.

31. Lamouille S, Xu J and Derynck R: Molecular mechanisms of epithelial-mesenchymal transition. Nat Rev Mol Cell Biol 15: 178-196, 2014.

32. Song J: EMT or apoptosis: A decision for TGF-beta. Cell Res 17: 289-290, 2007.

33. Morrison CD, Parvani JG and Schiemann WP: The relevance of the TGF- $\beta$ paradox to EMT-MET programs. Cancer Lett 341: 30-40, 2013.

34. Willis BC and Borok Z: TGF- $\beta$-induced EMT: Mechanisms and implications for fibrotic lung disease. Am J Physiol Lung Cell Mol Physiol 293: L525-L534, 2007.

35. Wendt MK, Tian M and Schiemann WP: Deconstructing the mechanisms and consequences of TGF- $\beta$-induced EMT during cancer progression. Cell Tissue Res 347: 85-101, 2012.

36. Zhao HW, Li YW, Feng R, Yu JB, Li J, Zhang Y, Li JC and Wang YX: TGF- $\beta /$ Smad $2 / 3$ signal pathway involves in U251 cell proliferation and apoptosis. Gene 562: 76-82, 2015.

37. Liu Z, Bandyopadhyay A, Nichols RW, Wang L, Hinck AP, Wang S and Sun LZ: Blockade of autocrine TGF- $\beta$ signaling inhibits stem cell phenotype, survival, and metastasis of murine breast cancer cells. J Stem Cell Res Ther 2: 1-8, 2012.
38. Liu J, Liao S, Diop-Frimpong B, Chen W, Goel S, Naxerova K, Ancukiewicz M, Boucher Y, Jain RK and Xu L: TGF- $\beta$ blockade improves the distribution and efficacy of therapeutics in breast carcinoma by normalizing the tumor stroma. Proc Natl Acad Sci USA 109: 16618-16623, 2012

39. Lu XS, Sun W, Ge CY, Zhang WZ and Fan YZ: Contribution of the PI3K/MMPs/Ln-5 $\gamma 2$ and EphA2/FAK/Paxillin signaling pathways to tumor growth and vasculogenic mimicry of gallbladder carcinomas. Int J Oncol 42: 2103-2115, 2013.

40. Chen HH, Zhou XL, Shi YL and Yang J: Roles of p38 MAPK and JNK in TGF- $\beta 1$-induced human alveolar epithelial to mesenchymal transition. Arch Med Res 44: 93-98, 2013.

41. Milone MR, Pucci B, Bruzzese F, Carbone C, Piro G, Costantini S, Capone F, Leone A, Di Gennaro E, Caraglia M, et al: Acquired resistance to zoledronic acid and the parallel acquisition of an aggressive phenotype are mediated by p38-MAP kinase activation in prostate cancer cells. Cell Death Dis 4: e641, 2013.

42. Yi Y, Kim HJ, Mi P, Zheng M, Takemoto H, Toh K, Kim BS, Hayashi K, Naito M, Matsumoto Y, et al: Targeted systemic delivery of siRNA to cervical cancer model using cyclic RGD-installed unimer polyion complex-assembled gold nanoparticles. J Control Release: Aug 30, 2016. pii: S01683659(16)30626-5. doi: 10.1016/j.jconrel.2016.08.041.

43. Basha G, Ordobadi M, Scott WR, Cottle A, Liu Y, Wang H and Cullis PR: Lipid nanoparticle delivery of siRNA to osteocytes leads to effective silencing of SOST and inhibition of sclerostin in vivo. Mol Ther Nucleic Acids 5: e363, 2016. 